\title{
Analyzing the Parameters of Multidimensional Poverty in Taluka Naushahro Feroze: A Case Study
}

\author{
Adnan Mustafa Palh ${ }^{1}$, Muhammad Anwar Solangi ${ }^{1}$, Syed Feroz Ali Shah ${ }^{1}$, Zohaib Ali Qureshi ${ }^{2}$ \\ 1. Department of Basic Sciences and Related Studies, Mehran University of Engineering and Technology, \\ Jamshoro, Sindh, Pakistan. \\ 2. Institute of Mathematics and Computer Science, University of Sindh, Jamshoro, Sindh Pakistan
} \begin{abstract}
This research paper tackles the multidimensional poverty applying Foster and Alkire methods of Taluka Naushahro Feroze's 14 Union councils on the basic figures. No any single navigator gives clear value for deprivation as naturally it is multidimensional. Three dimensions are selected having unequal weights in health, education, and living standard. These areas have been extra distributed in ten indicators, two for education, two for health while six for living standards. The out-put shows that Union Council Waggan has the most multidimensional poverty while least multidimensional poverty was found in Union Councils of Cheeho Taluka Naushahro Feroze. It further suggests an indicator which has highest contributions for multidimensional poverty such as life expectancy, child school attendance, school quality, child mortality, year of schooling, walls, cooking fuel, overcrowding and which contribute lowest is electricity and improved drinking water. Percentage of people for those who are MPI poor of Taluka Naushahro is $47.95 \%$ (incidence of poverty), while average deprivation of people is $55.75 \%$ furthermore, multidimensional poverty index (MPI) is $26.73 \%$ in Naushahro Feroze.
\end{abstract}

Keywords: Multidimensional poverty, incidence of poverty, Average deprivation

DOI: $10.7176 /$ JPID/53-06

Publication date: March $31^{\text {st }} 2020$

\section{INTRODUCTION}

Multidimensional deprivation has many factors hence it is multidimensional in nature. Poverty cannot be calculated by income alone. Multidimensional poverty is affected to deprived people such as poor health, starvation, access of pure drinking water and school attendance. Researchers around the world are taking various parameters to measure the multidimensional poverty. Most agreed multidimensional parameters of poverty around the world are education, health and living standard. Basically, these are three dimensions of multidimensional poverty. It can be observed that those having higher education have better health as well as their living standard is also better. On the contrary, people have higher income does not mean that their standard of education, health and living standard is better. Therefore, if we work on these parameters of poverty, we shall be able to give source of income to the people who are facing the menace of poverty rather the income. To calculate poverty, we require to establish multidimensional poverty tactics. It shows actual value of poverty.

\section{METHODOLOGY}

Population of Naushahro Feroze has been selected (Step 1) and as a sample we selected randomly fourteen Union Councils for primary data (Step 2). By using Krejci and Morgan table sample size 300 was chosen (Step 3). These 300 Questionnaires were asked to selected people of Union Councils for establishing multidimensional poverty index (Step 4). MPI is created by using Alkire and Foster method. 
Step 1: Sample size collection

\begin{tabular}{cccc}
\hline Population & $\begin{array}{c}\text { Average No. of members } \\
\text { from each house }\end{array}$ & No. of houses & Sample Size \\
\hline 384874 & 7.3 & $384874 / 7.3 \approx 52722$ & 300 \\
\hline
\end{tabular}

Step 2: Households numbers from each Union council

\begin{tabular}{ccc}
\hline Number of U-C & Selected U-C & $\begin{array}{c}\text { Average No. of houses from } \\
\text { each U-C }\end{array}$ \\
\hline 21 & 14 & $300 / 14 \approx 21$ \\
\hline
\end{tabular}

Step 3: Randomly selected union councils

\begin{tabular}{|c|c|c|c|c|l|l|}
\hline UC-01 & UC-02 & UC-03 & UC-04 & UC-05 & UC-06 & UC-07 \\
\hline Bhambri & Cheeho & Abran & Noor Pur & Thatt & Phull & Waggan \\
\hline UC-08 & UC-09 & UC-10 & UC-11 & UC-12 & UC-13 & UC-14 \\
\hline Dangeja & Chanari & Masurjiah & Veesar & Koor hassan & Sarhal & Bhurind \\
\hline
\end{tabular}

$\mathrm{YS}=$ Year of Schooling

$\mathrm{CSA}=$ Child School Attendance

$\mathrm{SQ}=$ School Quality

$\mathrm{CM}=$ Child Mortality

$\mathrm{LE}=$ Life Expectancy

$\mathrm{E}=$ Electricity

IDW $=$ Improved Drinking Water

$\mathrm{W}=\mathrm{Walls}$

$\mathrm{CF}=$ Cooking Fuel

$\mathrm{OC}=$ Overcrowding

Above abbreviations are used in table A.

Step 4: Deprivation cut off for collecting basic data

Table: A

\begin{tabular}{lcll}
\hline Dimensions & Indicator & Deprived if... & Weight \\
\hline ES & CSA & $\begin{array}{l}\text { Five years of schooling has domestic member } \\
\text { has no completed. } \\
\text { Any School-aged child is not joining school up }\end{array}$ & $1 / 9$ \\
& SQ & $\begin{array}{l}\text { An class } 8 . \\
\text { Disadvantaged if any child is not going to school } \\
\text { for the reason that of quality issues (not enough }\end{array}$ & $1 / 9$ \\
& & $\begin{array}{l}\text { teacher, school are distant away, too costly, no } \\
\text { male/female teacher, substandard schools), or } \\
\text { attending school but remains dissatisfied with } \\
\text { service }\end{array}$ \\
\hline
\end{tabular}




\begin{tabular}{|c|c|c|c|}
\hline \multirow{2}{*}{ Health } & $\mathrm{CM}$ & Any child perished in the household & $1 / 6$ \\
\hline & LE & $\begin{array}{l}\text { Average life is less the anticipated lifetime in the } \\
\text { world }\end{array}$ & $1 / 6$ \\
\hline \multirow{5}{*}{$\begin{array}{l}\text { Living } \\
\text { Standard }\end{array}$} & $\mathrm{E}$ & The household has no electricity & $1 / 15$ \\
\hline & IDW & $\begin{array}{l}\text { The family does not have contact to pure water or } \\
\text { harmless water is additional than a 10-minute } \\
\text { away from house. }\end{array}$ & $1 / 15$ \\
\hline & $\mathrm{W}$ & $\begin{array}{l}\text { Family has unrestored walls (mud, uncooked/mud } \\
\text { bricks, wood/bamboo) }\end{array}$ & $1 / 15$ \\
\hline & $\mathrm{CF}$ & The household does not cook with natural gas & $1 / 15$ \\
\hline & $\mathrm{OC}$ & $\begin{array}{l}\text { Family is overloaded ( } 4 \text { or more persons per } \\
\text { room) }\end{array}$ & $1 / 15$ \\
\hline
\end{tabular}

\section{Mathematical Equations:}

Step 5: formulation of deprivation matrix by basic data. Every individual is represented by each row and each indicator is represented by each column in deprivation matrix.

Deprivation Matrix $=\left[\begin{array}{cccc}b_{11} & b_{12} & \cdots & b_{1 n} \\ b_{21} & b_{22} & \cdots & b_{2 n} \\ \vdots & \vdots & \vdots & \vdots \\ b_{m 1} & b_{m 2} & \cdots & b_{m n}\end{array}\right]$

Step 6: Score vector and censored deprivation matrix Score vector shows the score of each individual which is primarily the sum of entire row for each individual. Multidimensional poverty dual cut off is formed to establish censored deprivation matrix.

Step 7: Headcount ratio

$$
H=\frac{p}{n}
$$

Here "H denotes the Incidence of people whose share of weighted deprivation is k or more" and whole population is represented by $\mathrm{n}$ and persons who are multidimensional poor is represented by $\mathrm{p}$.

Step 8: Intensity Level.

Intensity of poor individuals can be calculated by the sum of poverty encountered by the poor divided by number of poor people. Which mathematically can be written as.

$$
A=\sum_{i=1}^{n} \frac{d_{i}(k)}{p}
$$

Here $\operatorname{di}(\mathrm{k})$ is the censored deprivation of people $\mathrm{i}$ and $\mathrm{p}$ is the number of individuals who are multidimensional deprived.

Step 9: Calculating the MPI

MPI is an output of intensity level and Head Count Ratio: $\mathrm{M}=\mathrm{A} \times \mathrm{H}$

H: Head count Ratio

A: Intensity level of people who are poor

Step 10: Formula to calculate Multidimensional Poverty.

Each indicator's contribution $\mathrm{n}$ to MPI $=\frac{U C_{n} C H_{n}}{M P I_{\text {naushahro feroze }}} \times 100$ 
Where $U C_{n}$ is the weight attach to indicator $\mathrm{n}$. Where $C H_{n}$ is the censored deprivation score vector of indicator n.

\section{RESULTS AND DISCUSSIONS}

(Fig-1) displays that UC Abran has the highest incidence of poverty and least in UC Bhambri. (Fig-1) more indicates that MPI is least in UC Bhambri whereas Highest in UC Abran.. Sarhal and Masurjiwah collectively have the second highest percentage of deprived while UC Koor Hassan and UC Masurjiwah has the second highest average deprivation faced by poor people (Fig. 1). (Table. 2) shows that highest involvement to the MPI in taluka Naushahro Feroze is shared by the indicator life expectancy while the least contribution to the MPI is contributed by the indicator improved drinking water. Contribution of each indicator to the MPI differs in each Union Councils.
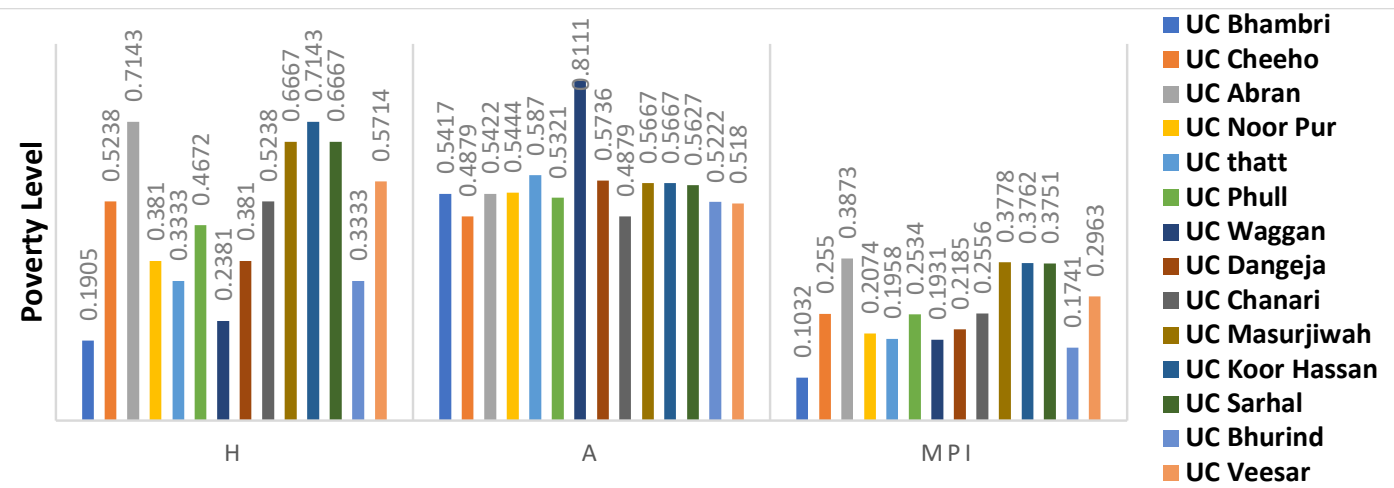

Figure 1: Incidence of poverty, average deprivation and MPI of people who are poor

Table1: Incidence of poverty, average deprivation and MPI

\begin{tabular}{|c|l|l|l|l|l|l|l|}
\hline UC & Sarhal & phull & waggan & Veeser & thatt & Noor pur & $\begin{array}{l}\text { Koor } \\
\text { hasan }\end{array}$ \\
\hline $\mathrm{H}$ & 0.6667 & 0.4762 & 0.2381 & 0.5714 & 0.3333 & 0.3810 & 0.7143 \\
\hline $\mathrm{UC}$ & Dangeeja & cheeho & Masurjiwah & Chanari & Bhurind & Bhambri & Abran \\
\hline $\mathrm{H}$ & 0.3810 & 0.5238 & 0.6667 & 0.5238 & 0.3333 & 0.1905 & 0.7143 \\
\hline $\begin{array}{l}\mathrm{H} \\
\text { OVERALL }\end{array}$ & \multicolumn{7}{|c|}{0.4795} \\
\hline
\end{tabular}

\begin{tabular}{|c|l|l|l|l|l|l|l|}
\hline UC & Sarhal & phull & Waggan & Veeser & That & Noor pur & $\begin{array}{l}\text { Koor } \\
\text { hasan }\end{array}$ \\
\hline $\mathrm{A}$ & 0.5627 & 0.5322 & 0.8111 & 0.5185 & 0.5873 & 0.5444 & 0.5267 \\
\hline UC & dangeja & Cheeho & Masurjiwah & Chanari & Bhurind & Bhambri & Abran \\
\hline $\mathrm{A}$ & 0.5736 & 0.4879 & 0.5667 & 0.4879 & 0.5222 & 0.5417 & 0.5422 \\
\hline $\begin{array}{l}\mathrm{A} \\
\text { OVERALL }\end{array}$ & \multicolumn{7}{|c|}{0.5575} \\
\hline
\end{tabular}




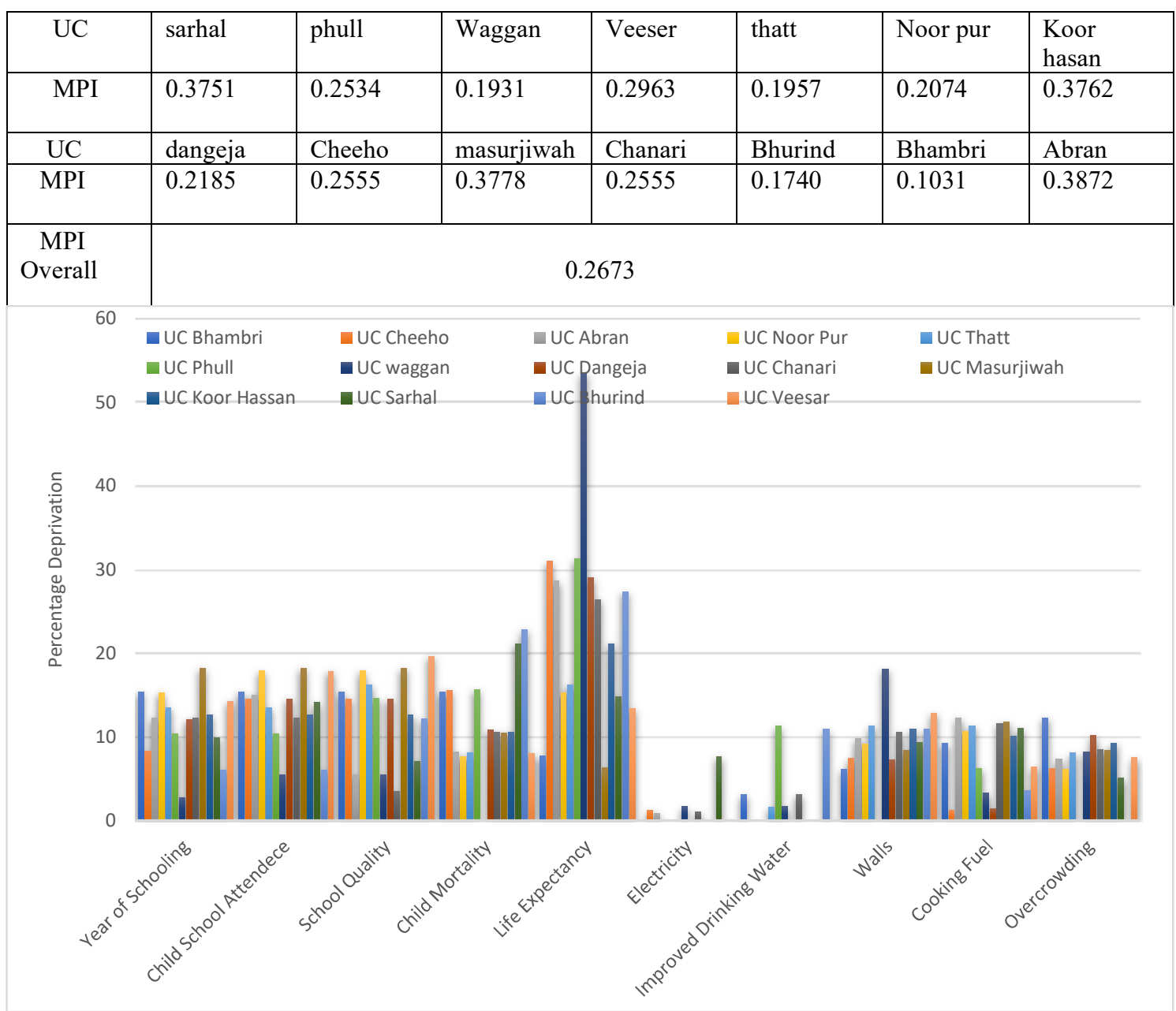

Figure. 2: contribution of each indicator to MPI

Table2: Contribution of each indicator to MPI

\begin{tabular}{|l|l|l|l|l|l|l|l|l|l|l|l|l|l|l|}
\hline & sarhal & Phull & Waggan & veeser & That & $\begin{array}{l}\text { Noor } \\
\text { Pur }\end{array}$ & $\begin{array}{l}\text { Koor } \\
\text { hasan }\end{array}$ & dangeja & cheeho & $\begin{array}{l}\text { Masurji } \\
\text { wah }\end{array}$ & chanari Bhurind bhambri abran \\
\hline Year of schooling & 9.8733 & 10.439 & 2.739 & 14.285 & 13.514 & 15.306 & 12.658 & 12.107 & 8.280 & 18.206 & 12.324 & 6.078 & 15.383 & 12.295 \\
\hline $\begin{array}{l}\text { Child school } \\
\text { attendance }\end{array}$ & 14.1042 & 10.439 & 5.478 & 17.857 & 13.514 & 17.857 & 12.658 & 14.528 & 14.493 & 18.206 & 12.324 & 6.078 & 15.383 & 15.027 \\
\hline School Quality & 7.0528 & 14.614 & 5.478 & 19.642 & 16.217 & 17.857 & 12.658 & 14.538 & 14.493 & 18.206 & 3.520 & 12.156 & 15.383 & 5.463 \\
\hline Child mortality & 21.1570 & 15.657 & 0 & 8.035 & 8.107 & 7.652 & 10.548 & 10.895 & 15.527 & 10.503 & 10.563 & 22.795 & 15.383 & 8.197 \\
\hline Life expectancy & 14.8100 & 31.315 & 53.425 & 13.392 & 16.217 & 15.306 & 21.097 & 29.055 & 31.056 & 6.302 & 26.409 & 27.355 & 7.693 & 28.688 \\
\hline Electricity & 7.6164 & 0 & 1.644 & 0 & 0 & 0 & 0 & 0 & 1.242 & 0 & 1.056 & 0 & 0 & 0.820 \\
\hline $\begin{array}{l}\text { Improved } \\
\text { Drinking Water }\end{array}$ & 0 & 0 & 1.644 & 0 & 1.622 & 0 & 0 & 0 & 0 & 0 & 3.169 & 0 & 3.078 & 0 \\
\hline Walls & 9.3085 & 11.273 & 18.081 & 12.857 & 11.352 & 9.183 & 10.970 & 7.263 & 7.453 & 8.403 & 10.563 & 10.942 & 6.152 & 9.836 \\
\hline Cooking fuel & 11.0018 & 0 & 3.286 & 6.428 & 11.352 & 10.715 & 10.126 & 1.453 & 1.242 & 11.764 & 11.619 & 10.942 & 9.230 & 12.295 \\
\hline Overcrowding & 5.0776 & 6.262 & 8.218 & 7.500 & 8.107 & 6.123 & 9.282 & 10.170 & 6.210 & 8.403 & 8.450 & 3.646 & 12.309 & 7.377 \\
\hline Total & 100 & 100 & 100 & 100 & 100 & 100 & 100 & 100 & 100 & 100 & 100 & 100 & 100 & 100 \\
\hline
\end{tabular}




\section{CONCLUSION}

Multidimensional poverty in Taluka Naushahro Feroze is $26.73 \%$, while incidence of poverty who are facing poverty is $47.95 \%$ while $55.75 \%$ is level of intensity. Many people of Taluka Naushahro Feroze's people are deprived in life expectancy while this is contributing most in every selected union councils of Naushahro Feroze. For instance, most of the people of UC Waggan are deprived in life expectancy whereas less contributing in UC Masurjiwah. In the same way large individuals of UC Masurjiwah are deprived in the year of schooling on the other hand less people are deprived in UC Waggan. Therefore, urgently steps should be taken for the development of the life expectancy and the year of schooling.

\section{REFRENCES}

QURESHI,, Z.A., SOLANGI,, M.A., SHAIKH,, A.A. and SAHITO,, J.GM., 2018. Measuring Multidimensional Parameters Of Poverty Using Alkire And Foster Methodology In Qasimabad: A Case Study. [online] Iiste.org. Available at: <https://www.iiste.org/Journals/index.php/JPID/article/view/42894/45486> [Accessed 30 June 2018].

Saleem, H., Shabbir, M. S., \& Khan, B. (2019). Re-examining Multidimensional Poverty in Pakistan: A New Assessment of Regional Variations. Global Business Review, 0972150919844412.

Mahmood, T., Yu, X., \& Klasen, S. (2019). Do the Poor Really Feel Poor? Comparing Objective Poverty with Subjective Poverty in Pakistan. Social Indicators Research, 142(2), 543-580.

Waqas, M., \& Torre, A. (2019). Political favoritism and social conflict: a case study of the Benazir Income Support Programme (BISP) in Pakistan. Area Development and Policy, 1-16.

Santos, M. E. (2019). Challenges in designing national multidimensional poverty measures.

Mazhar, M. S., Bajwa, B. E., McEvilly, G., Palaniappan, G., \& Kazmi, M. R. (2019). Improving Vegetable Value Chains in Pakistan for Sustainable Livelihood of Farming Communities. Journal of Environmental and Agricultural Sciences, 18, 1-9.

Alkire, S., \& Fang, Y. (2019). Dynamics of multidimensional poverty and uni-dimensional income poverty: An evidence of stability analysis from China. Social Indicators Research, 142(1), 25-64.

Hameed, A., \& Qaiser, Z. (2019). Estimating Social Exclusion in Rural Pakistan: A Contribution to Social Development Policies. Business \& Economic Review, 11(1), 103-122.

Ihsan, N., \& Aziz, B. (2019). A Multidimensional Analysis of Quality of Life: Pakistan's Context. Social Indicators Research, 142(1), 201-227.

Ullah Awan, R., Arif, M., Raza Cheema, A., \& Rahim, S. (2019). An Empirical Analysis of Employment Status, Nature of Employment and Poverty Incidence in Pakistan. European Online Journal of Natural and Social Sciences: Proceedings, $8(2$ (s)), pp-18.

Gul, F., Jan, D., \& Ashfaq, M. (2019). Assessing the Impact of Climate Change Adaptation Strategies on Poverty Rates of Wheat Farmers in Khyber Pakhtunkhwa, Pakistan. Sarhad Journal of Agriculture, 35(2), 442-448. 